\title{
ANALISIS HUBUNGAN HARGA TIMAH BKDI DAN LME SERTA KEBIJAKAN EKSPOR TERHADAP KINERJA EKSPOR TIMAH INDONESIA
}

\section{Causality Analysis of Tin Price in BKDI and LME and Export Policy on the Indonesian Tin Export Performance}

\author{
Hasni \\ Pusat Kebijakan Perdagangan Luar Negeri, BP2KP, Kementerian Perdagangan-RI \\ JI. M.I. Ridwan Rais No. 5 Jakarta Pusat, 10110 \\ email: hasni.melati@gmail.com
}

Naskah diterima: 01/12/2014 Naskah direvisi: 03/12/2015 Disetujui diterbitkan: 30/07/2015

\begin{abstract}
Abstrak
Timah merupakan bahan tambang yang tidak terbarukan. Indonesia menempati peringkat kedua sebagai produsen bijih timah terbesar dunia. Sejak 30 Agustus 2013, ekspor timah Indonesia harus melalui mekanisme transaksi di Bursa Komoditi dan Derivatif Indonesia (BKDI). Penelitian ini bertujuan untuk menganalisis hubungan antara harga timah BKDI dan harga timah di London Metal Exchange (LME) serta kebijakan ekspor terhadap kinerja ekspor timah Indonesia. Data yang digunakan merupakan data sekunder dari BKDI, LME, Asian Metal dan BPS. Hasil penelitian dengan menggunakan metode Granger causality menunjukkan bahwa setelah satu tahun penerapan ekspor timah melalui BKDI, harga timah BKDI dipengaruhi oleh harga timah LME pada rentang waktu satu hari kerja. Dari sisi penerimaan ekspor, kebijakan ekspor melalui BKDI dapat meningkatkan nilai ekspor timah bulanan ke Singapura. Pemerintah harus melanjutkan kebijakan ekspor timah yakni ekspor melalui Bursa Komoditi dan Derivatif Indonesia untuk mencegah ekspor timah ilegal dan meningkatkan daya saing serta nilai tambah produk timah ekspor Indonesia.
\end{abstract}

Kata kunci: Timah, Ekspor, BKDI, Granger Causality

\begin{abstract}
Tin is a non-renewable mineral. Indonesia is the second largest producer of tin ore in the world. Since August 30 2013, Indonesian tin export has been done through The Indonesia Commodity and Derivatives Exchange (ICDX) transaction mechanism. This study aims to analyze the relationship between ICDX's tin price and the London Metal Exchange (LME) price as well as the effect of tin export mechanism through ICDX on the Indonesia's tin export performance. The secondary data were taken from BKDI, LME, Asian Metal and BPS. The results showed that using Granger causality analysis, after one year the policy is being implemented, there is a relationship between ICDX's tin price and LME price on one (working days) time lag. Tin export policy through ICDX mechanism can increase the value of monthly tin exports to Singapore, therefore it increases the export earning. The government needs to continue the tin export policy through the ICDX to prevent illegal tin export as well as to strenghten the competitiveness and value added of Indonesian tin export.
\end{abstract}

Keywords: Tin, Export, ICDX, Granger Causality

JEL Classification: C31, F12, Q31 


\section{PENDAHULUAN}

Indonesia terletak pada jalur timah terkaya di Asia Tenggara dan dunia yang dikenal sebagai south east tin belt. Jalur timah di Indonesia meliputi Pulau Bangka, Pulau Belitung, Singkep, dan Kundur serta perairan di sekitar wilayah tersebut (Anaperta, 2012). Indonesia menduduki peringkat kedua sebagai negara produsen timah dengan jumlah produksi pada tahun 2013 sebanyak
64 ribu ton. Sementara China pada tahun yang sama menghasilkan 99 ribu ton timah. Indonesia merupakan salah satu negara eksportir terbesar timah dunia dengan pangsa pasar $30 \%$. Negara lain yang juga memproduksi timah diantaranya Peru, Bolivia dan Brazil dengan produksi masing-masing sebesar 42 ribu ton, 16 ribu ton dan 12 ribu ton (Gambar 1).

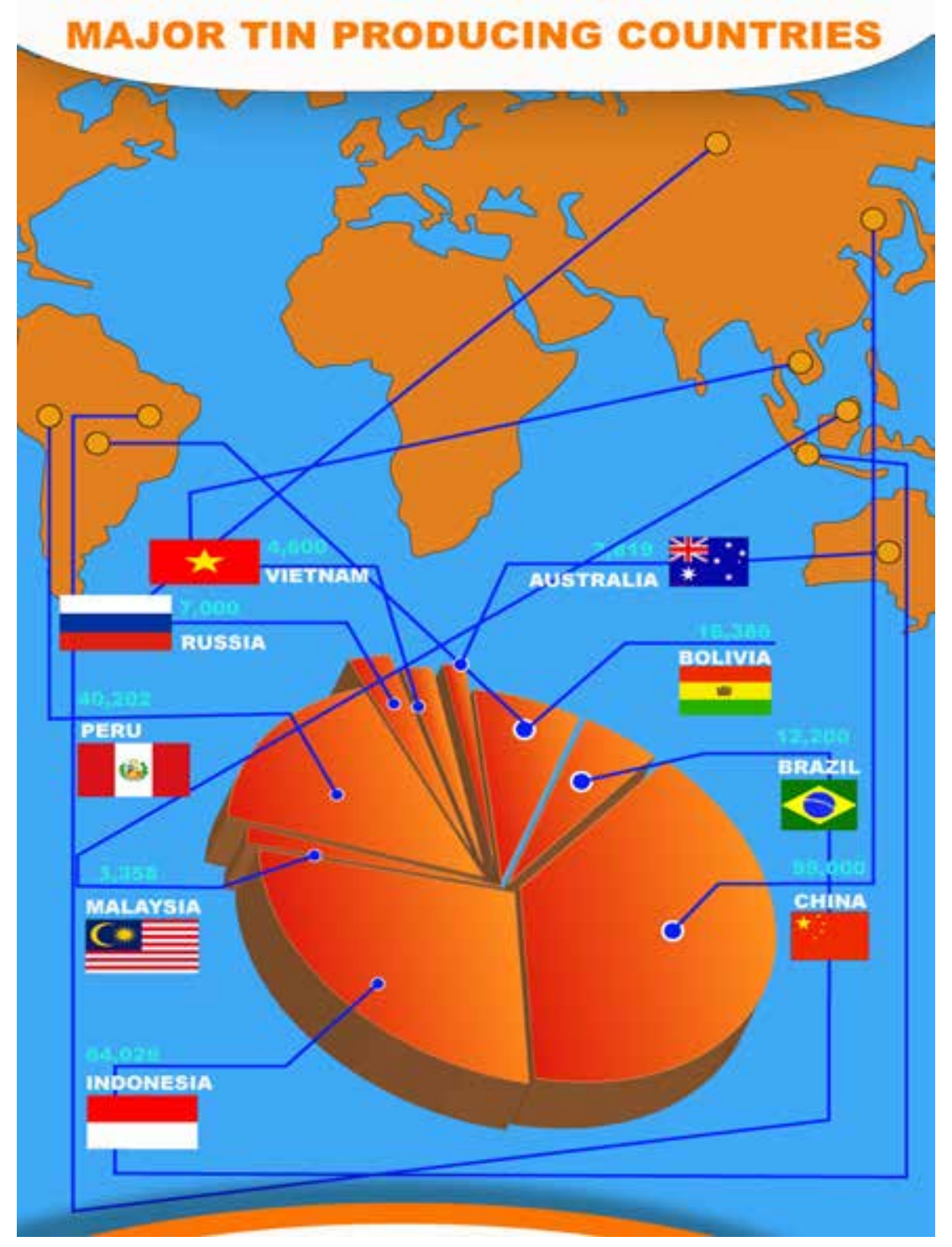

Gambar 1. Negara Produsen Timah Dunia Tahun 2013 (Ton)

Sumber: Think energy (2014) 
Kebutuhan timah dunia sekitar 360.000 ton/tahun, dan terus meningkat seiring dengan perkembangan teknologi industri dan gaya hidup manusia. Timah putih digunakan sebagai bahan pelapis logam, selain itu timah putih juga dapat meningkatkan performa dari suatu material, mencegah timbulnya korosi dan memperindah tampilan logam lain. Proses pelapisan logam dengan menggunakan timah putih disebut Tinning atau Sn plating (Sutrisno, 2013).

Kettle (2014) menyatakan bahwa pasokan timah dunia yang semakin menipis dan permintaan pasar yang dihadapkan dengan defisit pasokan, mengakibatkan peningkatan harga timah pada 3-4 tahun mendatang dengan perkiraan kisaran harga antara USD 30.000-USD 35.000 atau lebih per ton.

Peningkatan harga dapat menyokong pengembangan proyek pertambangan timah yang baru di Afrika Selatan, Bolivia dan Brazil sehingga pasokan dan permintaan diharapkan kembali balance.

International Tin Research Institute (ITRI) Ltd. memperkirakan di tahun 2015 permintaan timah global mencapai 400.000, terutama akibat industrialisasi di China, meningkatnya permintaan produk elektronik dan transisi yang cepat dalam penggunaan timah solder. Pertumbuhan permintaan timah global diperkirakan terus meningkat, terlebih lagi akibat perkembangan produk elektronik yang cepat, yang sangat mebutuhkan timah solder (Hutton, 2014).

Demikian juga dengan produk pertambangan utama dunia lainnya seperti Manganese ferroalloys yang peningkatan produksi dan konsumsinya berdampak pada peningkatan produksi baja dan infrastruktur global. Selama periode 2001 hingga 2010 peningkatan produksi manganese ferroalloys dunia sebanyak dua kali lipat khususnya peningkatan kapasitas produksi di Asia dan Oceania (Steenkamp \& Basoon, 2013).

Bojanic (2009) mengungkapkan bahwa timah memberikan pengaruh yang besar terhadap perekonomian Bolivia selama kurun waktu 19502007. Secara konsisten harga timah dan pangsa ekspor timah menjamin kelancaran ekonomi di Bolivia. Selain itu terdapat hubungan yang kuat dalam jangka panjang antara GDP per kapita Bolivia dengan harga timah. Hal ini sebagai bukti industri timah berperan besar dalam meningkatkan kesejahteraan penduduk Bolivia.

Di Indonesia sendiri, produksi timah sekitar $68,5 \%$ yang dihasilkan oleh industri smelter (industri yang memproses konsentrat bijih timah menjadi logam timah) yang berlokasi di Provinsi Bangka Belitung. PT. Timah (Persero) Tbk. merupakan perusahaan smelter terbesar di Bangka Belitung. Dari ekspor tahun 2013 yang jumlahnya mencapai 100.000 ton, PT. Timah menyumbang 23.237 ton atau sekitar $23,3 \%$ dari total ekspor timah. Industri smelter timah swasta lainnya menyumbang hingga 76.763 ton atau sekitar 76,7\% (Bisnis.com, 2014).

Harga timah di bursa LME (London Metal Exchange), yang selama ini dijadikan sebagai acuan harga timah dunia, pernah mencapai tingkat paling rendah pada level USD 17.000 per ton 
pada tahun 2013 (Gatra, 2014), bahkan pernah di level USD 15.000 per ton pada tahun 2010. Harga timah dunia yang rendah menimbulkan banyak kerugian, baik bagi pengusaha timah maupun pemerintah. Namun demikian, penambang pasirtimah merupakan pihak yang menderita kerugian paling besar karena penurunan harga timah dunia oleh pengusaha smelter akan langsung dibebankan kepada penambang pasir timah. Pada bulan Januari 2014, ketika harga timah dunia turun dari USD 26.970 per ton menjadi USD 22.074 per ton, pembelian pasir timah oleh kolektor turun sangat signifikan dari Rp 120.000 per kilogram, menjadi Rp 108.000 per kilogram (Bappebti, 2014).

Sementara itu, bagi Indonesia kerugian yang ditanggung dari turunnya harga timah dunia, adalah berkurangnya penerimaan baik dalam bentuk devisa maupun royalti. Jika harga ekspor timah rendah maka penerimaan pemerintah dalam bentuk devisa maupun royalti akan menurun, meskipun volume ekspornya meningkat.

Guna mengantisipasi terjadinya penurunanhargatimahakibatpersaingan diantara para pengusaha smelter, pemerintah mengeluarkan Peraturan Menteri Perdagangan (Permendag) 32/M-DAG/PER/6/2013, yang mengatur perdagangan ekspor timah melalui mekanisme transaksi bursa berjangka di Bursa Komoditi dan Derivatif Indonesia (BKDI) atau Indonesia Commodity and Derivatif Exchange (ICDX). Permendag tersebutjuga bertujuan untuk menjadikan Indonesia sebagai referensi harga timah dunia, menggantikan LME. Keinginan ini didasari pada peran Indonesia yang selama ini sebagai negara eksportir timah terbesar dengan pangsa sekitar $30 \%$ dari total ekspor timah dunia (Bisnis.com, 2014).

Namun harga timah BKDI yang relatif lebih tinggi dibandingkan dengan harga timah di bursa LME belum bisa dijadikan indikasi bahwa BKDI sebagai price reference harga timah dunia. Pada Gambar 2 ditunjukkan bahwa selama periode Maret - April 2014, harga timah di bursa internasional berfluktuasi antara USD 10,35 per pound (sekitar USD 22.817/ton) hingga USD 10,6 per pound (sekitar USD 23.369/ton). Fenomena fluktuasi harga timah di pasar dunia bisa jadi merupakan respon dari fluktuasi harga timah di BKDI, atau sebaliknya.

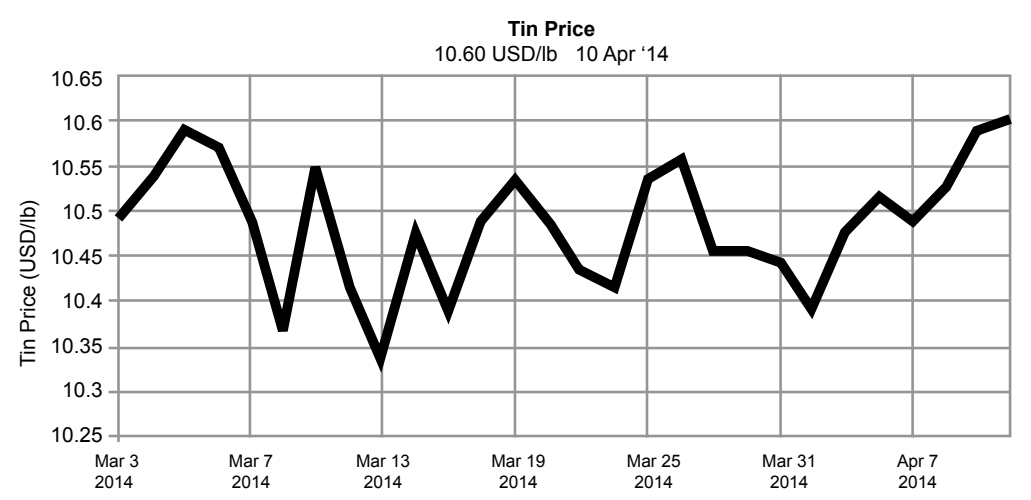

Gambar 2. Fluktuasi Harga Timah di Bursa Internasional (USD/lb)

Sumber: Infomine (2014) 
Dari penjabaran latar belakang di atas, yang menjadi masalah utama adalah apakah benar harga timah di Bursa Komoditi dan Derivatif Indonesia (BKDI) dapat saling mempengaruhi dengan harga timah di London Metal Exchange (LME), dan apakah ekspor timah melalui mekanisme transaksi di BKDI dapat meningkatkan kinerja ekspor timah Indonesia. Penelitian ini bertujuan untuk menganalisis pengaruh harga timah di BKDI terhadap harga timah di LME dan menganalisis pengaruh harga timah di BKDI terhadap kinerja ekspor timah Indonesia.

\section{METODE}

Sebagai alat analisis, penelitian ini menggunakan Uji Granger causality method untuk melihat pengaruh harga timah di BKDI terhadap harga timah di LME, sedangkan untuk melihat permintaan timah, penelitian ini menggunakan metode regresi linear berganda dan analisis deskriptif. Data sekunder yang digunakan dalam analisis ini berasal dari BKDI, LME, Asian Metal dan BPS. Data yang bersumber dari BKDI dan BPS diperoleh langsung dari instansi tersebut, sedangkan data LME dan Asian Metal diunduh melalui website masing-masing.

\section{Uji Granger causality method dan analisis cointegrasi}

Kemampuan uji Granger causality melihat hubungan variabel secara langsung, tergantung pada kemampuan untuk mengukur semua interaksi variabel yang relevan dalam sistem yang dianalisis (Guo et al., 2008).
Dalam analisis Granger causality, pendefinisian yang tepat dari informasi yang dibutuhkan juga sangat penting. Mengabaikan pendefinisian informasi secara jelas dapat menyebabkan model sulit untuk dipahami dan ditafsirkan (Baumohl \& Vyrost, 2010). Granger causality merupakan metode yang kuat untuk mengidentifikasi interaksi variabel dalam data time series. Granger causality menerapkan fungsi statistik, yang menggunakan data untuk membantu memprediksi, dan mengetahui dampak suatu variabel (Seth et al., 2015). Salah satu contoh penelitian yang menggunakan Granger causality adalah penelitian Ray (2012) yang menganalisis tentang globalisasi dan pertumbuhan ekonomi di India. Hasil analisis menunjukkan terdapat hubungan kausalitas dua arah antara tingkat globalisasi dan pertumbuhan ekonomi di India.

Pengaruh harga timah di BKDI terhadap harga timah di LME, dianalisis dengan menggunakan metode Granger causality. Hasil analisis dimaksudkan untuk melihat ada tidaknya pengaruh harga BKDI terhadap harga LME. Analisis dilanjutkan untuk melihat besarnya cointegrasi menggunakan model yang sesuai. Model yang sesuai ditetapkan berdasarkan hasil analisis stasioneritas. Apabila datanya stasioner, maka digunakan model VAR (vector autoregression), sebaliknya jika tidak stasioner menggunakan model VECM (vector error correction model) untuk mengetahui keeratan pengaruh tersebut dan jeda waktu (time lag) yang diperlukan untuk mempengaruhi. 
Setelah pengaruh harga timah di bursa BKDI dengan harga timah di bursa LME diketahui, langkah selanjutnya menganalisis kekuatan prediksi (predictive power) dari informasi tersebut, untuk menunjukkan adanya hubungan kausalitas antara harga timah BKDI dan harga timah LME dalam jangka waktu lama. Data yang digunakan merupakan harga rata-rata harian (khusus hari kerja), dari bulan September 2013 hingga Agustus 2014 $(n=244)$.

Model Granger Causality dinyatakan dalam persamaan, sebagai berikut:

$$
\begin{aligned}
& X_{t}=\sum_{i=1}^{n} \alpha_{i} Y_{t-i}+\sum_{j=1}^{n} \beta_{j} X_{t-j}+\mu_{1 t} \ldots . . \\
& Y_{t}=\sum_{i=1}^{m} \gamma_{i} Y_{t-i}+\sum_{j=1}^{m} \delta_{j} X_{t-j}+\mu_{2 t} \ldots . .
\end{aligned}
$$

\begin{tabular}{|c|c|}
\hline$x_{t}$ & $\begin{array}{l}\text { : Harga timah di bursa LME } \\
\text { pada periode } \mathrm{t}\end{array}$ \\
\hline$x_{t-i}$ & $\begin{array}{l}\text { :Harga timah di bursa LME } \\
\text { pada periode } t-i\end{array}$ \\
\hline$Y_{t}$ & : harga timah di bursa BKDI \\
\hline$Y_{t-j}$ & $\begin{array}{l}\text { :Harga timah di bursa BKDI } \\
\text { pada periode } t-j\end{array}$ \\
\hline$t, i, j$ & $\begin{array}{l}\text { :tanggal hari kerja selama } \\
\text { periode analisis }\end{array}$ \\
\hline$\alpha, y$ & $\begin{array}{l}\text { : koefisen variabel harga timah } \\
\text { di bursa BKDI }\end{array}$ \\
\hline
\end{tabular}

Dimana:

$\beta, \delta \quad$ :koefisien variabel harga timah di bursa LME $\mu_{1 \mathrm{t}}$ dan $\mu_{2 \mathrm{t}}$ : errorterms yang diasumsikan tidak mengandung korelasi serial $\mathrm{n}=\mathrm{m}=1,2,3, \ldots \ldots, 244$

Kausalitas Granger dilihat dengan membandingkan nilai $F_{\text {statistik }}$ dengan nilai kritis $\mathrm{F}_{\text {tabel }}$ pada tingkat signifikansi $(0,01)$ dan membandingkan besarnya nilai probabilitas dengan tingkat signifikansi $(0,01)$ (Firdaus, 2004). Jika nilai $F_{\text {statistik }}$ (dari) $Y$ does not Granger Cause $X$ dan $X$ does not Granger Cause $Y$ lebih besar dari (>) nilai kritis $F_{\text {tabel }}$ dan nilai probabilitas (dari) $Y$ does not Granger Cause $X$ dan $X$ does not Granger Cause $Y$ kurang dari (<) tingkat signifikansi $(0,01)$ (atau signifikan pada taraf nyata $1 \%)$, berarti terdapat kausalitas dua $\operatorname{arah}(\mathrm{YX})$.

Jika nilai $F_{\text {statistik }} Y$ does not Granger Cause $X$ lebih besar dari (>) nilai kritis $F_{\text {tabel }}$ dan nilai probabilitas $Y$ does not Granger Cause $X$ kurang dari (<) tingkat signifikansi $(0,01)$ maka signifikan. Jika nilai $\mathrm{F}_{\text {statistik }} X$ does not Granger Cause $Y$ kurang dari $(<)$ nilai kritis $F_{\text {tabel }}$ dan jika nilai probabilitas $X$ does not Granger Cause $Y$ lebih besar dari ( $>$ ) tingkat signifikansi $(0,01)$ maka tidak signifikan. Hal ini berarti terdapat kausalitas satu arah $(Y X)$. Jika nilai $F_{\text {statistik }} Y$ does not Granger Cause $X$ kurang dari $(<)$ nilai kritis $F_{\text {tabel }}$ dan nilai probabilitas $Y$ does not Granger Cause $X$ lebih besar dari $(>)$ tingkat signifikansi $(0,01)$ maka tidak signifikan.

Jika nilai $\mathrm{F}_{\text {statistik }} X$ does not Granger Cause $Y$ lebih besar dari $(>)$ nilai kritis $F_{\text {tabel }}$ dan jika nilai probabilitas $X$ does not Granger Cause $Y$ kurang dari (<) tingkat signifikansi $(0,01)$ maka signifikan. Hal ini berarti terdapat kausalitas satu arah $(X Y)$. Jika nilai $F_{\text {statistik }}$ baik $Y$ does not Granger Cause $X$ maupun $X$ does not Granger Cause $Y$ kurang dari (<) nilai kritis $F_{\text {tabel }}$ dan nilai probabilitas baik $Y$ does not Granger Cause $X$ maupun 
$X$ does not Granger Cause $Y$ lebih besar dari $(>)$ tingkat signifikansi $(0,01)$ maka tidak signifikan yang berarti tidak terdapat kausalitas.

Analisis pengaruh harga timah BKDI terhadap kinerja ekspor timah Indonesia

Dalam analisis ini kebijakan di BKDI menjadi variabel dummy eksogen (independent), dan nilai ekspor timah negara tujuan menjadi variabel endogen (dependent). Karena permintaan timah tidak hanya dipengaruhi oleh adanya harga BKDI, maka dalam model juga dimasukkan variabel lain yang mempengaruhi permintaan timah yaitu harga, dan volume ekspor. Dummy variable yang digunakan dalam model penduga ekspor HS 8001 adalah nol untuk periode sebelum di BKDI, dan 1 untuk periode setelah di BKDI.

$Y i=\alpha+\beta 1 H i+\beta 2 V i+\gamma \mathrm{D}$

Dimana:

$\mathrm{Y}$ : nilai ekspor timah

$\alpha$ : konstanta

$\beta 1$ : koefisen variable harga timah

$H i$ : harga timah

$\beta 2$ : koefisien variable volume ekspor timah

$V i$ : volume ekspor timah

$\mathrm{Y}$ : koefisien dummy BKDI

$i$ : periode

Data yang digunakan dalam kajian ini berupa data sekunder yang diperoleh dari BKDI, LME, BPS, dan Asian Metal. Tabel 1 menunjukkan rincian data yang digunakan dalam analisis timah ini.

Tabel 1. Data Sekunder

\begin{tabular}{rll}
\hline No. & Sumber Data & Data yang digunakan \\
\hline 1 & BKDI & Harga timah BKDI \\
2 & LME & Harga timah LME \\
3 & BPS & Nilai dan volume ekspor timah Indonesia \\
4 & Asian Metal & Harga timah Asian Metal \\
\hline
\end{tabular}

Untuk menganalisis dampak kebijakan ekspor timah melalui BKDI terhadap ekspor timah Indonesia, digunakan model permintaan ekspor timah dengan menggunakan variable dummy sebelum dan sesudah adanya kewajiban ekspor melalui BKDI. Variabel dummy tersebut untuk melihat perbedaan kinerja ekspor antara sebelum dan setelah diberlakukannya kebijakan ekspor timah melalui BKDI.

Data yang digunakan untuk membuat model penduga permintaan ekspor adalah data bulanan harga ekspor, volume ekspor, nilai ekspor, dan Gross Domestic Product (GDP). Dari UN Comtrade, kelengkapan data yang diperlukan tersebut hanya ekspor ke negara Singapura dan ke Timor Leste. Namun karena ekspor ke Timor Leste nilainya relatif kecil, maka tidak bisa digunakan dalam model. Sehingga model disusun menggunakan data ekspor ke Singapura. Pada pembahasan sebelumnya juga di jelaskan bahwa negara tujuan ekspor timah didominasi oleh Singapura, dari Singapura selanjutnya dijual kepada pembeli selanjutnya yang berasal dari berbagai negara. 
Model permintaan ekspor dibedakan antara HS 8001 (tin ingot/timah murni batangan)dengan $\mathrm{HS} 8003$ (bentuktimah lainnya seperti tin bars, rods, profiles and wire). Variabel yang digunakan untuk kedua model tersebut tidak semua sama, karena disesuaikan dengan taraf nyata pengaruh masing-masing variable penduga. Persamaan ekonometrik yang digunakan untuk menyusun model HS 8001 (timah batangan dan sudah wajib diperdagangkan melalui BKDI) dan HS 8003 (timah solder dan belum wajib diperdagangkan melalui BKDI) adalah model regresi linier berganda.

\section{Pengaruh BKDI terhadap ekspor Timah HS 8001}

Model penduga ekspor HS 8001 dibangun dengan menggunakan data bulanan dari Januari 2013 hingga Juni 2014. Data ekspor yang digunakan adalah nilai ekspor (USD). Model yang sesuai adalah persamaan regresi berganda least square, dengan nilai ekspor(USD)sebagaivariabledependent yang merupakan transformasi logaritma natural (In) dari model ekponensial. Koefisien variable penduga model, AR (1) merupakan variable lag (t-1), yang merupakan variable tambahan untuk menghilangkan masalah autokorelasi sehingga hasil regresi yang dibangun bersifat BLUE (best linear unbiased estimators) (Greene, 2003).

\section{HASIL DAN PEMBAHASAN}

\section{Permendag 32/M-DAG/PER/6/2013 Meminimalisir Ekspor Timah llegal}

Indonesia Corruption Watch (ICW) mengungkapkan bahwa rendahnya data ekspor timah yang tercatat di Indonesia dengan data di negara importir menjadi indikasi adanya kerugian negara yang timbul akibat ekspor timah ilegal. Selama tahun 2013 disinyalir Indonesia mengalami kerugian akibat penyelundupan timah sebesar USD 362.752 juta, nilai ini diduga berasal dari ekspor timah illegal yang mencapai 301.800 ton. Rincian dugaan kerugian negara tersebut terdiri dari kerugian royalti timah (3\% dari nilai ekspor) sebesar USD 130.754 juta dan PPh Badan (rata-rata $20 \%$ ) sebesar USD 231.998 juta (Koran Tempo, 2014).

Sementara menurut Irawan, dkk (2014) model bisnis timah yang diterapkan saat ini menunjukkan bahwa pemerintah daerah, pemerintah pusat dan lembaga penegak hukum memiliki kepentingan yang tinggi dan sangat mempengaruhi kondisi pertimahan di Bangka Belitung. Saat ini upaya yang dilakukan oleh pemerintah pusat adalah dengan mewajibkan para eksportir menjual produksi timahnya melalui BKDI sejak Agustus 2013, selain agar dapat mencegah terjadinya ekspor timah ilegal, juga meningkatkan pendapatan negara melalui penerimaan royalti produk timah sebesar 3\% dari nilai ekspor, serta meningkatkan nilai tambah dan daya saing ekspor produk timah Indonesia.

Timah yang diekspor jenisnya dinamis sesuai dengan peraturan perdagangan yang diberlakukan pada saat itu, mulai dari bahan baku pasir timah yang belum diolah, sampai timah murni batangan yang merupakan end product dari pertambangan timah. Tahapan pengolahan timah secara garis besar ditunjukkan pada Gambar 3. 


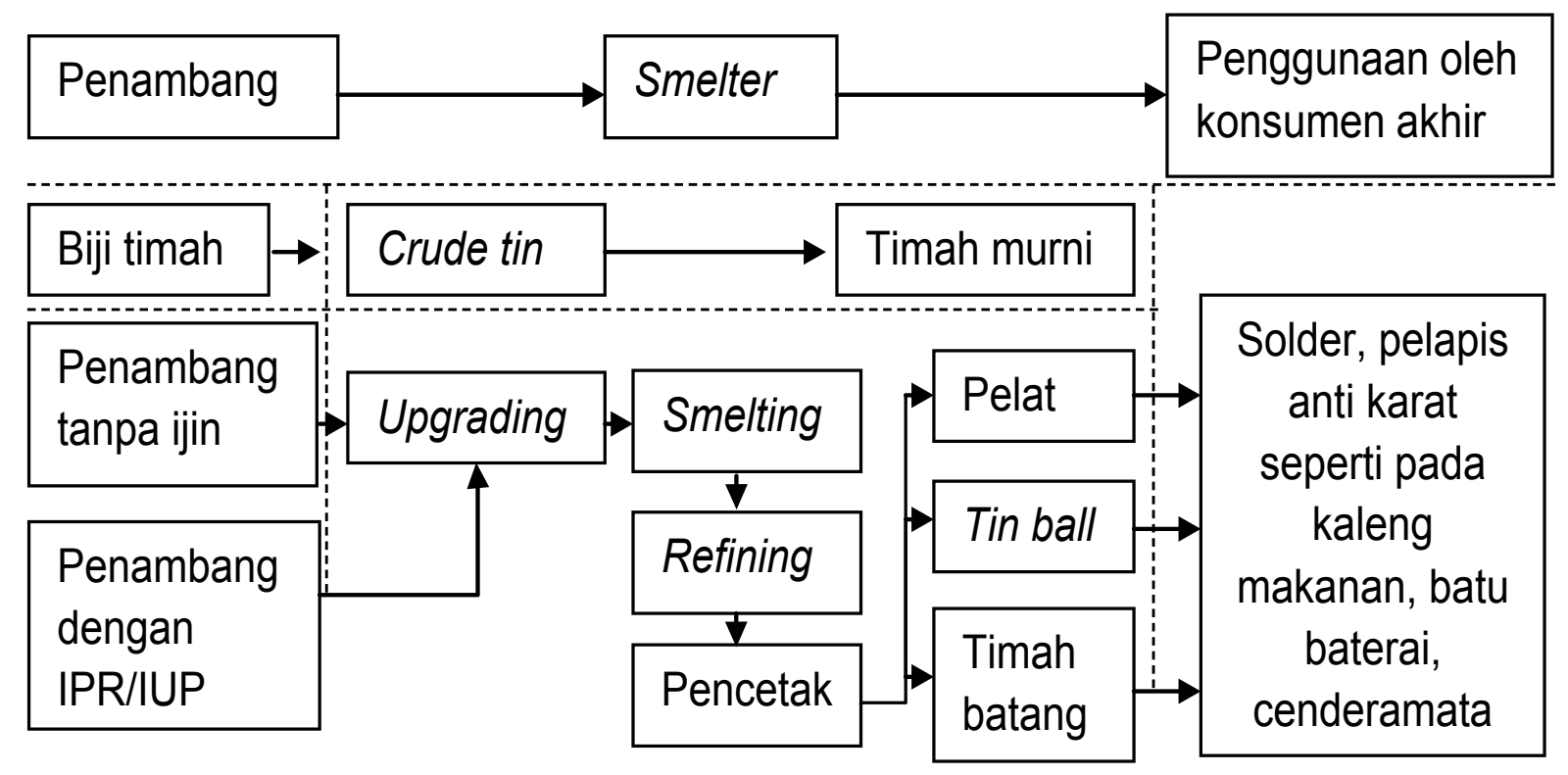

Gambar 3. Tahapan Pengolahan Timah

Sumber: Mareta (2011), diolah

Sebelum tahun 2006, biji timah (ore) dapat diekspor secara bebas. Bahkan ore sering dicampur dengan pasir untuk menghindari pembayaran royalti. Larangan ekspor tin ore yang diberlakukan sejak tahun 2006, mendorong para smelter berinvestasi mesin tannur untuk memproses tin ore menjadi timah batangan kemudian diekspor. Kandungan stannum (Sn) pada produk timah batangan yang diekspor sebelum Permendag 32 tahun 2013 diterapkan cukup bervariasi. Mulai dari timah murni sampai timah batangan dengan kandungan Sn yang rendah (crude tin), sesuai dengan permintaan buyer.

Timah batangan yg dihasilkan smelter banyak yang memiliki kandungan Sn rendah, untuk dijual ke trading Singapura dengan cara ijon (dibayar dimuka). Crude tin dari trading Singapura tersebut kemudian dibeli oleh perusahaan refinery yang ada di Malaysia, Thailand, China untuk diolah menjadi timah murni. Banyaknya jenis timah yang diperdagangkan membuka peluang terjadinya penyelundupan untuk menghindari pembayaran royalti. Sistem ijon yang dilakukan trading dari Singapura, diduga menjadi pemicu petani untuk melakukan penambangan timah secara ilegal.

Tahun 2012 dikeluarkan Permendag No. 78 untuk mengatur perdagangan timah yang diharapkan bisa meningkatkan nilai tambah industri pengolahan timah dalam negeri, sekaligus meningkatkan penerimaan negara dari royalti. Dalam Permendag No. 78 tahun 2012 disebutkan bahwa timah batangan yang boleh diekspor sejak 1 Januari 2013 memiliki kandungan Sn minimum 99,85\%, dan mulai Juli 2013 kandungan Sn minimum meningkat menjadi 99,9\%. 
Banyaknya pintu pelabuhan ekspor, menyulitkan pengawasan terhadap pelaksanaan Permendag No. 78 tahun 2012. Oleh karena itu, dikeluarkanlah Permendag No. 32 tahun 2013, yang mewajibkan ekspor timah dilakukan melalui bursa, sehingga tidak ada lagi kebocoran penerimaan royalti yang dilakukan eksportir ilegal. Dalam Permendag No. 32 tahun 2013 tercantum bahwa mulai tanggal 1 Juli 2013, Timah batangan dan timah dalam bentuk lainnya dapat diekspor jika kadar Sn minimum 99,9\%, dan 0,1\% lainnya adalah pengotor yang terdiri dari $\mathrm{Fe}$ maksimum 0,005\% dan $\mathrm{Pb}$ maksimum $0,030 \%$.

Untuk mendapatkan timah putih batangan dengan kadar 99,9\%, diperlukan tiga tahap proses refining (pemurnian) yaitu pory refining (mendapatkan kadar 99,92\%), eutectic refining, dan electrolytic refining (kadar timah 99,9\%). Tidak semua smelter memiliki teknologi pemurnian tersebut, namun antar smelter dapat melakukan kerjasama untuk menghasilkan timah batang dengan kadar sesuai ketentuan.

\section{Perkembangan Harga Timah Dunia Sebelum dan Sesudah Mekanisme BKDI}

Sebelum 30 Agustus 2013 dimana Pemendag 32/2013 belum diterapkan, harga ekspor timah mengacu pada harga di bursa LME (London Exchange Market). Dalam beberapa tahun terakhir, harga timah di bursa LME berfluktuasi sangat tajam, mulai dari terendah USD 15.000/MT pada Februari 2010 hingga mendekati USD 35.00/MT pada bulan April 2011. Periode lain dimana harga timah batangan dibawah USD 20.000/ MT terjadi pada Januari 2012, Agustus 2012 dan Agustus 2013 (Gambar 4).

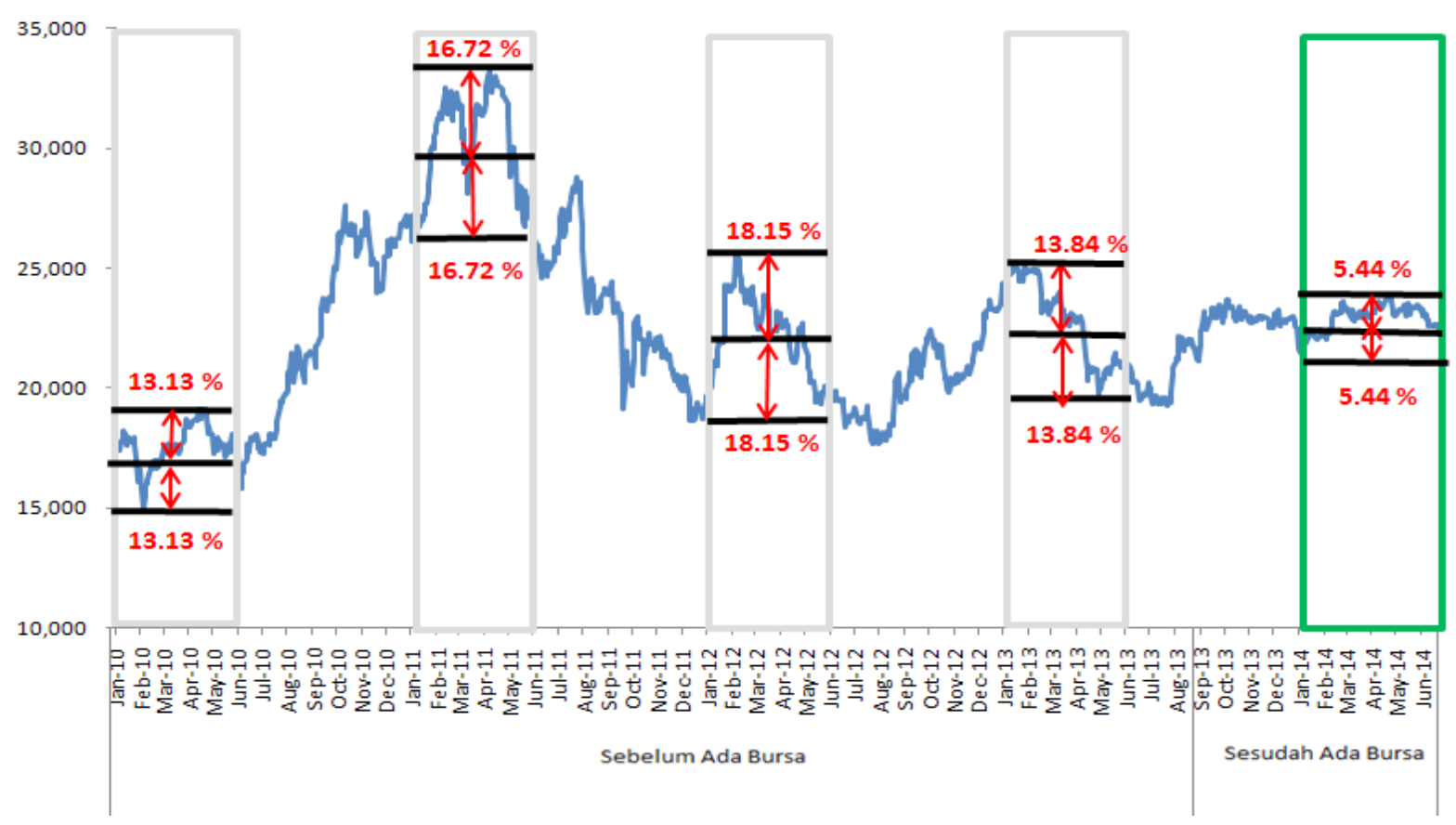

Gambar 4. Fluktuasi harga timah di bursa LME sebelum BKDI

Sumber: LME (2014) dan BKDI (2014), diolah 
Sejak diberlakukannya kebijakan ekspor timah melalui bursa komoditi (BKDI) pada bulan Agustus 2013, fluktuasi harga timah di bursa LME relatif kecil. Kisaran harga timah per MT antara USD 21.000 sampai USD 24.000 (Gambar 5). Masuknya BKDI dalam perdagangan timah dunia merupakan pesaing baru yang dapat mengurangi dominasi perdagangan timah melalui LME. Mekanisme perdagangan timah melalui BKDI menyebabkan harga ekspor timah Indonesia lebih baik dibanding harga LME.

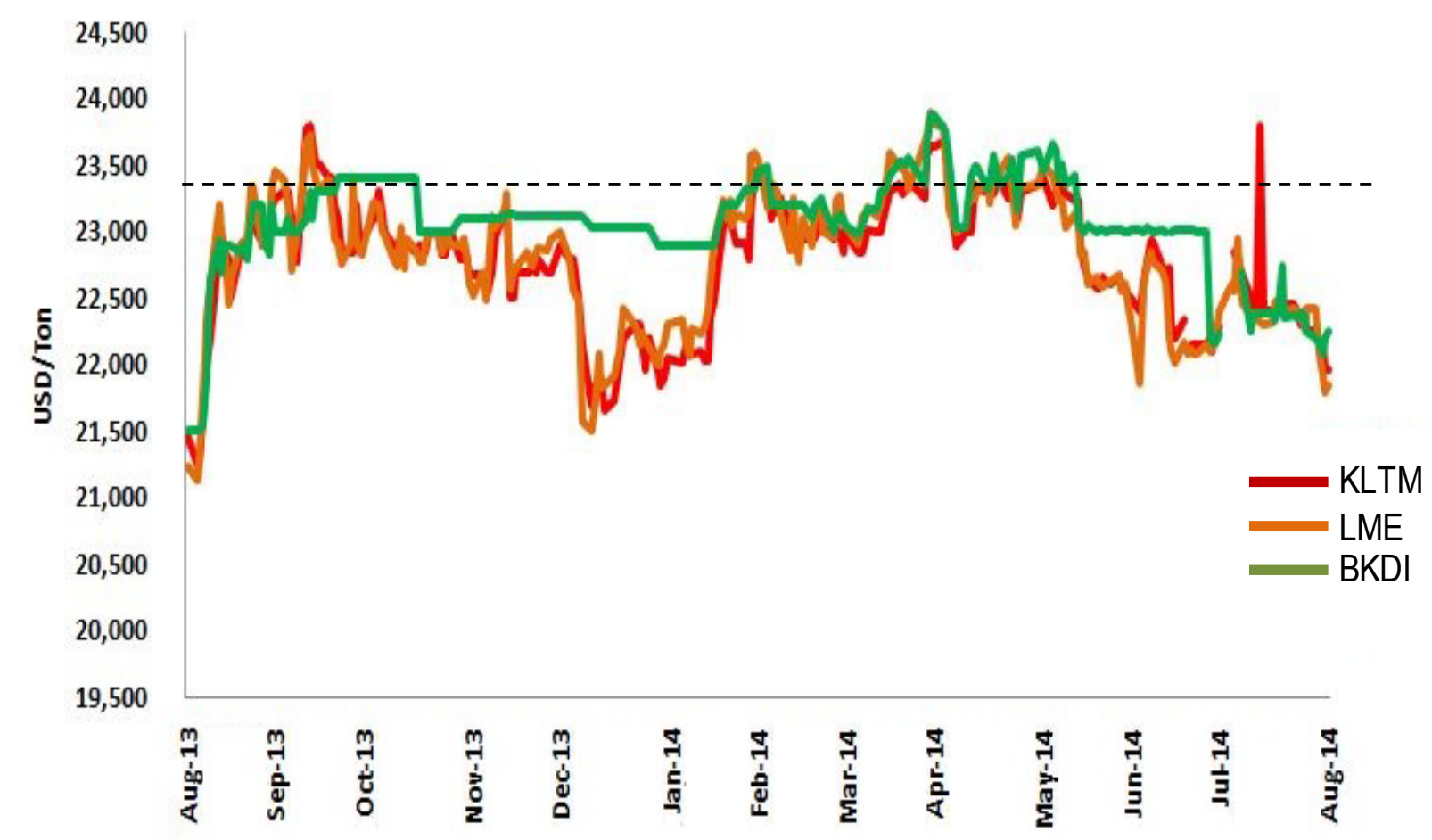

Sumber: BKDI (2014)

Gambar 5. Fluktuasi harga timah sesudah BKDI (USD/ton)

Apabila dicermati pada Gambar 5 terlihat bahwa harga penjualan timah melalui BKDI relatif lebih tinggi dibandingkan dengan harga di bursa LME dan KLTM. Di bursa BKDI pelaku perdagangan lebih banyak produsen/ smelter yang menginginkan harga relatif tinggi. Sementara di Bursa LME dan KLTM (Kuala Lumpur Tin Market), pelaku lebih didominasi oleh trader dan end user yang menginginkan harga rendah.

\section{Pengaruh Harga Timah BKDI dengan LME}

Berdasarkan hasil analisis Granger Causality dengan memasukkan lag-1 (jarak 1 hari) menunjukkan pengaruh yang nyata (probabilitas $<0,01$ ) antara harga di LME dengan harga di BKDI (Tabel 2). Artinya, harga timah di LME 1 hari kerja sebelumnya berpengaruh terhadap harga di BKDI hari ini, atau harga LME hari ini akan mempengaruhi harga di BKDI pada satu hari kerja berikutnya. 
Tabel 2. Keterkaitan antara harga timah di LME, BKDI dan Asian Metal

\begin{tabular}{lccc}
\hline Hipotesis nol & Obs & F-Statistic & Prob. \\
\hline BKDI does not Granger Cause ASME & 202 & 1,94542 & 0,1646 \\
ASME does not Granger Cause BKDI & 0,49631 & 0,4819 \\
\hline \hline LME does not Granger Cause ASME & 224 & 1,37051 & 0,2430 \\
ASME does not Granger Cause LME & & 0,45520 & 0,5006 \\
\hline LME (1) does not Granger Cause BKDI & 193 & 22,3756 & $4, E-06 * *$ \\
BKDI does not Granger Cause LME & & 0,16295 & 0,6869 \\
\hline \hline
\end{tabular}

Sumber: Hasil Analisis

Keterangan :

** nyata pada $1 \%$

Granger causality test telah dicoba dengan menggunakan lag t $=0,1$ dan 2 .

Untuk kombinasi hubungan kausalitas baik untuk BKDI dan ASME, maupun LME dan ASME telah dicoba dengan lag $\mathrm{t}=0,1$ dan 2 , namun tidak menunjukkan hasil yang signifikan

Namun pengaruh harga LME dengan harga BKDI tidak terjadi sebaliknya, atau harga BKDI tidak berpengaruh pada harga LME. Berdasarkan hasil analisis tersebut, harapan BKDI sebagai referensi harga timah dunia belum bisa tercapai. Namun, berdasarkan hasil FGD terungkap bahwa smelter anggota BKDI, optimis bahwa pada satu tahun ke depan (minimal setelah 2 tahun BKDI diberlakukan) keinginanan BKDI sebagai referensi harga perdagangan timah akan tercapai.

\section{Perkembangan Ekspor Timah Sebelum dan Sesudah Mekanisme BKDI}

Sekitar 95\% logam timah yang dihasilkan dari pertambangan timah di Indonesia untuk ekspor, sedangkan sisanya sebesar $5 \%$ untuk memenuhi permintaan pasar domestik. Sebelum Permendag 32/M-DAG/PER/6/2013 diterbitkan, ekspor timah selama periode Januari-Agustus 2013 termasuk ke dalam 10 komoditi non migas (HS 2 digit) dengan nilai ekspor terbesar.

Produk ekspor timah Indonesia untuk kategori HS 8001 mencapai sekitar 98\%, sisanya sebanyak $2 \%$ termasuk dalam kode HS 8003. Perkembangan ekspor timah selama periode 2008-2013, seperti ditunjukkan pada Gambar 6, volume ekspor untuk HS 8001 berada pada kisaran 92.277 hingga 110.372 ton per tahun. Tahun 2013, volumenya turun drastis menjadi hanya 88.441 ton. Penurunan volume 
ekspor yang terjadi pada tahun 2013, kemungkinan disebabkan oleh awal penerapan kebijakan ekspor timah melalui perdagangan di BKDI, dimana sampai bulan keempat sejak penerapan, volume ekspor jauh dibawah rata-rata bulanan tahun 2013 .

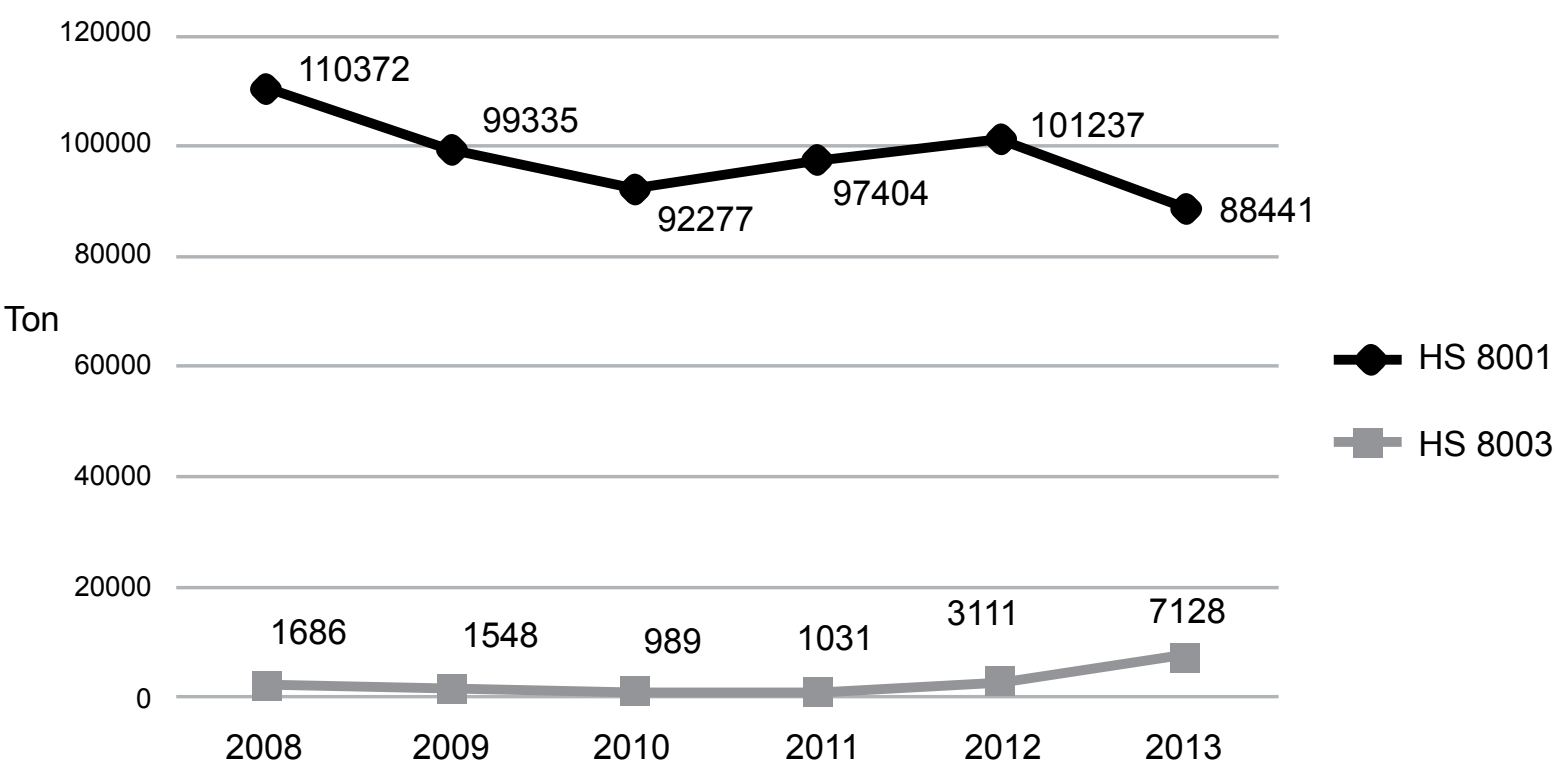

Sumber: BPS (2014), diolah

Gambar 6. Volume Ekspor Timah, 2008-2013 (ton)

Berbeda dengan HS 8001, volume ekspor HS 8003 justru meningkat setelah diberlakukan BKDI. Seperti ditunjukkan pada Gambar 6, dari tahun 2011 volume ekspor HS 8003 terus meningkat, hingga tahun 2013. Berkurangnya volume ekspor dari HS 8001, dikompensasi oleh pengusaha smelter timah dengan meningkatkan ekspor HS 8003, untuk mengamankan cash flow perusahaan.

Fluktuasi volume ekspor timah batangan setelah diberlakukan kebijakan ekspor timah melalui perdagangan di BKDI ditunjukkan pada Gambar 7. Volume ekspor sebelum timah diperdagangkan melalui BKDI rata-rata 100.000 ton, atau rata-rata sekitar 8.400 ton per bulan. Pada awal diberlakukannya BKDI, volume ekspor jauh dibawah rata-rata bulanan. Bulan kelima sejak diberlakukan kebijakan ekspor timah melalui BKDI yaitu bulan Desember 2013 volume ekspor timah kembali menunjukkan peningkatan yang siginfikan, namun terjadi penurunan kembali hingga bulan Agustus 2014. Nilai ekspor timah batangan selama periode September 2013 - Agustus 2014 tumbuh $14,5 \%$ per bulan, sedangkan volume ekspor timah batangan pada periode yang sama tumbuh $14,4 \%$ per bulan (Gambar 7). 


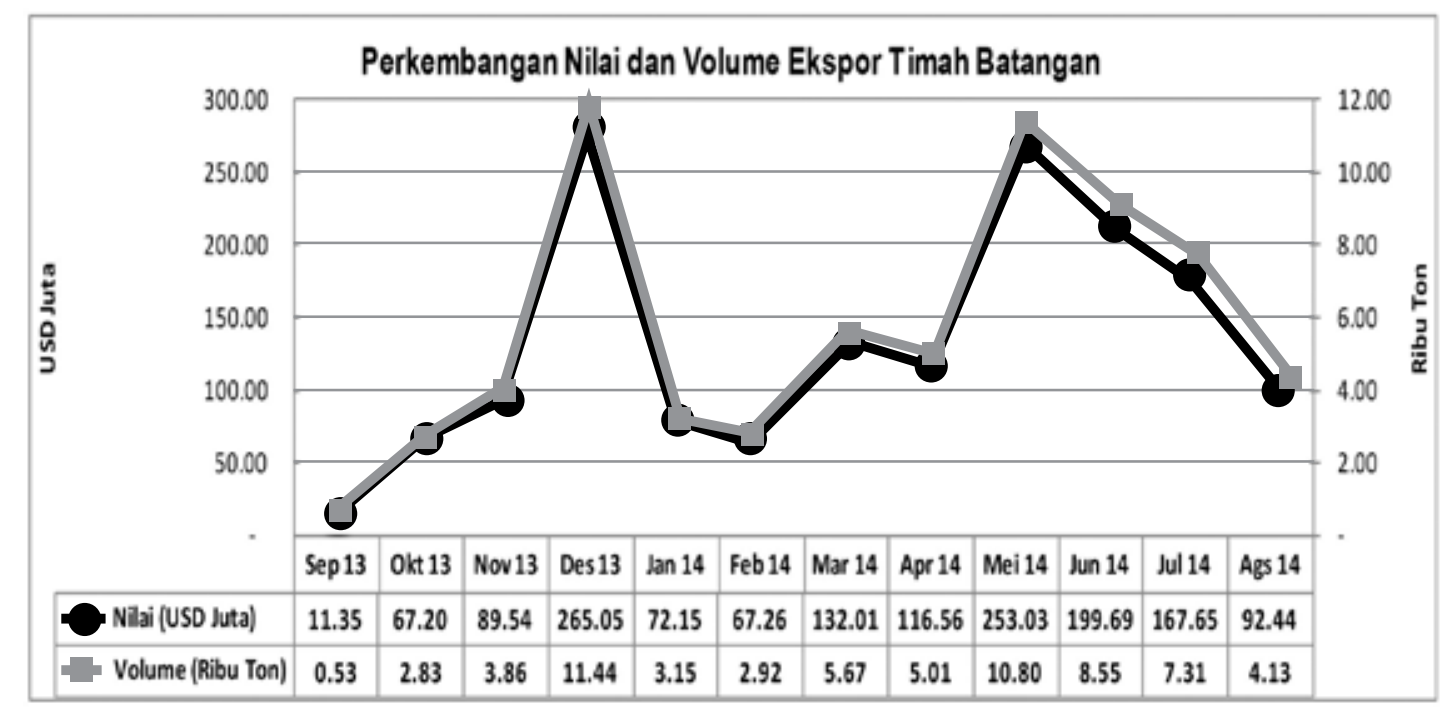

Gambar 7. Nilai dan Volume Ekspor Timah Batangan

Sumber: BPS (2014), diolah

Jika dilihat dari negara tujuan ekspor pada tahun 2014 (JanuariAgustus), ekspor timah paling dominan ke Singapura dengan pangsa $77,87 \%$ dari ekspor timah Indonesia ke pasar dunia (Tabel 3). Negara tujuan ekspor kedua yaitu Belanda, kemudian disusul Amerika Serikat dan India. Dari informasi yang diperoleh dengan pengusaha smelter timah, Singapura hanya sebagai negara transit sementara ekspor timah. Dari Singapura timah akan dijual kembali ke negara-negara lain yang membutuhkan.

Tabel 3. Negara Tujuan Ekspor Timah Melalui Perdagangan di BKDI Periode Januari-Agustus 2014

\begin{tabular}{lrrrr}
\hline \multicolumn{1}{c}{$\begin{array}{c}\text { Negara } \\
\text { Tujuan }\end{array}$} & \multicolumn{2}{c}{ Volume } & \multicolumn{2}{c}{ Nilai } \\
\cline { 2 - 5 } & Ribu Ton & Share (\%) & USD Juta & Share (\%) \\
\hline Singapura & 27.50 & 77.87 & 637.07 & 77.93 \\
Belanda & 2.98 & 8.43 & 68.13 & 8.33 \\
Jepang & 0.72 & 2.05 & 16.82 & 2.06 \\
AS & 1.39 & 3.92 & 32.29 & 3.95 \\
Korsel & 0.66 & 1.88 & 15.41 & 1.88 \\
India & 1.00 & 2.83 & 23.18 & 2.84 \\
Taiwan & 0.59 & 1.67 & 13.59 & 1.66 \\
Italia & 0.40 & 1.12 & 9.18 & 1.12 \\
Arab Saudi & 0.03 & 0.09 & 0.70 & 0.09 \\
Inggris & 0.01 & 0.01 & 0.12 & 0.01 \\
Malaysia & 0.02 & 0.06 & 0.47 & 0.06 \\
Turki & 0.03 & 0.07 & 0.58 & 0.07 \\
\hline Total & $\mathbf{3 5 . 3 2}$ & $\mathbf{1 0 0 . 0 0}$ & $\mathbf{8 1 7 . 5 3}$ & $\mathbf{1 0 0 . 0 0}$ \\
\hline
\end{tabular}

Sumber: BKDI (2014), diolah 


\section{Pengaruh Harga Timah BKDI Terhadap Ekspor Timah Indonesia}

Sejak 30 Agustus 2013, ekspor timah seluruhnya dilakukan melalui Bursa Komoditi dan Derivatif Indonesia (BKDI) sebagai implementasi dari Permendag 32/M-DAG/PER/6/2013. Timah yang akan diperdagangkan disimpan dalam gudang-gudang yang ditunjuk oleh BKDI, yang tersebar di beberapa pelabuhan daerah penghasil timah. Pengelola gudang menerbitkan "resi gudang" atas timah yang disimpan. Resi gudang tersebut digunakan sebagai bukti adanya barang yang bisa diperdagangkan dalam bursa. Buyerdan seller yang boleh melakukan transaksi di bursa, hanya yang terdaftar sebagai anggota bursa. Ketentuan tersebut diduga berpengaruh pada kinerja ekspor timah Indonesia.

Tabel 4. Hasil analisis model persamaan regresi nilai ekspor timah HS 8001

\begin{tabular}{lcccc}
\hline \multicolumn{1}{c}{ Variable } & Koefisien & Std. Error & t-Statistic & Prob. \\
\hline Ln_VOLUME_EKSPOR & 1,036670 & 0,014819 & 69,95409 & $0,0000^{* *}$ \\
Ln_GDP_SING & 0,401498 & 0,491399 & 0,817051 & 0,4276 \\
DUMMY & 0,079635 & 0,035822 & 2,223075 & $\left.0,0432^{* *}\right)$ \\
C & 1,531957 & 4,319304 & 0,354677 & 0,7281 \\
R-squared & 0,997078 & Mean dependent var & 11,90139 \\
Adjusted R-squared & 0,996452 & S.D. dependent var & 0,378985 \\
\hline
\end{tabular}

Sumber: Hasil analisis

**: nyata pada $5 \%$

Model yang digunakan adalah persamaan regresi berganda least square, dengan nilai ekspor sebagai variable dependent yang merupakan transformasi logaritma natural (In) dari model eksponensial, sehingga nilai ekspor timah HS 8001 ditunjukkan oleh persamaan berikut;

In nilai ekspor $=1,53+1,037 \ln \mathrm{V}+$ $0,402 \ln \mathrm{GDP}+0,080 \ln \mathrm{D}$

Dimana $V$ adalah volume ekspor (ton), GDP adalah Gross Domestic Product (USD ribu), dan D adalah variable dummy $(0$ untuk periode sebelum BKDI dan 1 untuk periode setelah BKDI). Pada Tabel 4 ditunjukkan bahwa variabel yang sangat baik untuk menduga nilai ekspor timah adalah volume ekspor (In_VOL_EKSPOR) dan kebijakan ekspor melalui BKDI (DUMMY) dengan nilai probabilitas masing-masing kurang dari $5 \%$ $($ Prob $<0,05)$. Nilai $R$-square model sangat tinggi (mendekati angka 1) yaitu 0,997 menunjukkan bahwa model penduga sangat bagus. Sebesar $99,7 \%$ fluktuasi penerimaan ekspor timah HS 8001 bisa dijelaskan oleh variable penduga secara bersamasama, sedangkan sisanya yang $0,3 \%$ dipengaruhi oleh variable lain yang tidak masuk dalam model. 
Variable GDP (Gross Domestic Product) yang mencerminkan daya beli di negara tujuan, tidak berpengaruh pada permintaan ekspor (Prob $>0,05$ ). Model ekspor yang dibangun hanya menggunakan data Singapura, dimana importir Singapura sebagian besar adalah trader. Impor timah tidak untuk dikonsumsi oleh masyarakat Singapura sendiri, namun dijual kembali ke negaranegara user. Oleh karena itu, variabel GDP Singapura tidak bisa digunakan sebagai penduga ekspor timah ke Singapura.

Nilai koefisien variabel penduga volume ekspor lebih besar dari 1 (yaitu 1,037), yang menunjukkan bahwa penerimaan ekspor elastis terhadap peningkatan volume ekspor. Jika volume naik $1 \%$, penerimaan ekspor meningkat lebih dari 1\% (yaitu 1,037\%). Penerimaan ekspor merupakan perkalian antara volume dengan harga. Laju peningkatan penerimaan ekspor yang lebih tinggi dibandingkan dengan laju peningkatan volume ekspor, mengindikasikan harga yang semakin tinggi dengan bertambahnya volume ekspor yang lebih kecil.

Dari sisi eksportir, harga jual tinggi merupakan insentif untuk meningkatkan volume ekspor. Pada saat harga timah dunia rendah, produsen timah yang tidak efisien akan menghentikan penambangan. Sebaliknya jika harga timah tinggi, tambang timah yang sebelumnya ditinggalkan karena produksinya rendah, menjadi layak untuk ditambang kembali. Oleh karena itu, harga timah tinggi, akan meningkatkan volume, dan secara bersama-sama akan meningkatkan penerimaan ekspor. Model penduga nilai ekspor timah HS 8001, menggunakan data periode Januari 2013 sampai Juni 2014. Pada periode tersebut kisaran harga ekspor timah antara USD 19,394.3/metric ton sampai USD $24,182.9 /$ metric ton. Apabila dibandingkan dengan rentang harga pada periode sebelumnya yang pernah mencapai harga tertinggi USD 30,019.48/metric ton (pada bulan April 2011), maka harga dalam model masih memungkinkan untuk naik.

Nilai koefisien variable penduga dummy BKDI positif (yaitu 0,080), artinya setelah diberlakukan BKDI ekspor timah HS 8001 meningkat dibandingkan dengan sebelum BKDI. Nilai perbedaan intercept model regresi linier dari logaritma natural (In) antara sebelum dan sesudah BKDI sebesar 0,080, atau setara dengan 1,08 ton (anti In 0,080). Kebijakan ekspor timah setelah BKDI yang hanya membolehkan ekspor timah dalam bentuk timah murni dengan kadar Sn $99,9 \%$, memaksa produsen untuk mengekspor timah dalam bentuk HS 8001, sehingga nilai ekspor HS 8001 meningkat.

Pada Gambar 8 ditunjukkan bahwa harga timah dunia yang terjadi sebelum timah diperdagangkan melalui BKDI selama periode Januari - Juli 2013, dan setelah adanya perdagangan timah di BKDI pada Agustus hingga Januari 2014 memiliki kisaran harga terendah dengan harga tertinggi berbeda. Sebelum melalui BKDI standar deviasinya selalu diatas $13 \%$, bahkan mencapai $18,15 \%$. Setelah perdagangan timah melalui BKDI, standar deviasinya hanya $5,44 \%$. 


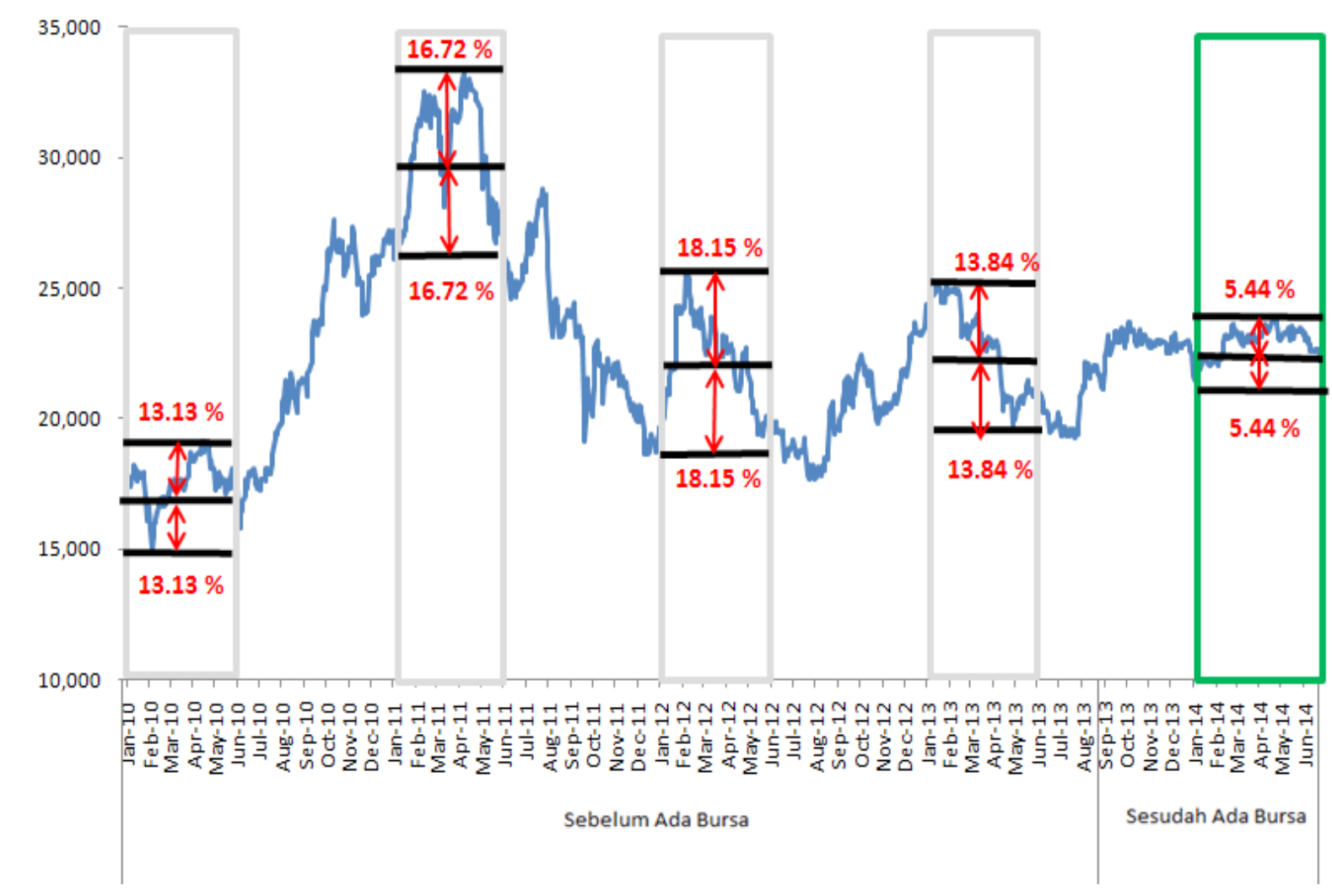

Gambar 8. Fluktuasi harga timah dunia sebelum dan sesudah BKDI (USD/MT) Sumber: Asian Metal (2014), diolah

Standar deviasi harga timah yang tinggi pada periode sebelum BKDI, menunjukkan bahwa timah merupakan komoditi spekulasi, dimana spekulator yang memiliki modal besar akan memainkan harga untuk mendapatkan keuntungan. Pada harga timah yang berfluktuasi, pihak yang paling diuntungkan adalah spekulator. Produsen timah lebih banyak mengalami kerugian. Seperti tampak pada Gambar 9. bahwa selama 4 periode pengamatan sebelum BKDI, hanya 1 kali harga di atas rata-rata setelah BKDI, dan tiga kali berada dibawah rata-rata BKDI.

Dibandingkan periode JanuariJuli 2013, harga timah batangan pada periode Januari-Juli 2014 (setelah BKDI), meningkat antara USD 500/MT sampai dengan USD 1000/MT. Oleh karena itu meskipun volume ekspor timah batangan menurun sekitar $20 \%$, namun karena harga jual yang tinggi, pengusahan smelter timah yang menjadi anggota (seller) BKDI keuntungannya mengalami peningkatan. Sebelum perdagangan timah melalui BKDI, keuntungan smelter antara USD 400-800/MT, setelah melalui BKDI keuntungan tersebut meningkat menjadi USD 4000-5000/MT (BKDI, 2014).

Harga timah menentukan kadartimah terendah ekonomis (COG/cut off grade). Pada tahun 2007 COG untuk endapan timah aluvial pada kisaran kadar $0,01 \%$ $\mathrm{Sn}$, atau cebakan bijih timah primer dengan kadar sekitar $0,1 \% \mathrm{Sn}$. Harga yang relatif tinggi setelah perdagangan 
timah dilakukan melalui BKDI, akan menurunkan COG. Sumberdaya timah dengan kadar rendah yang sebelumnya tidak ekonomis untuk diusahakan, dapat menjadi cadangan yang mempunyai nilai ekonomi. COG yang rendah, memberikan peluang pengembangan cebakan timah pada wilayah yang telah dilakukan pengakhiran tambang. Kondisi ini mendukung terlaksananya konservasi cadangan timah.

\section{KESIMPULAN DAN REKOMENDASI KEBIJAKAN}

Nilai ekspor timah batangan selama periode September 2013-Agustus 2014 tumbuh sebesar 14,5\% per bulan, sedangkan volume ekspor timah batangan pada periode yang sama tumbuh sebesar $14,4 \%$ per bulan. Hasil analisis Granger causality menunjukkan bahwa harga timah di bursa LME mempengaruhi harga timah di bursa BKDI dengan time lag (jeda) satu (1) hari kerja. Harga timah di bursa LME hari ini akan mempengaruhi harga timah di bursa BKDI keesokan harinya, atau harga timah di bursa BKDI dipengaruhi oleh harga timah di LME kemarin.

Kebijakan yang mewajibkan ekspor timah melalui BKDI meningkatkan nilai ekspor timah batangan (HS 8001) bulanan ke negara tujuan ekspor utama yaitu Singapura. Peningkatan nilai ekspor timah batangan disebabkan harga yang relatif tinggi dibandingkan sebelum BKDI. Pengusaha smelter timah tidak keberatan dengan kewajiban ekspor timah melalui bursa BKDI, namun perlu pengawasan yang lebih intensif dan audit dari lembaga independen, agar masyarakat semakin percaya terhadap transparansi kerja di BKDI. Pengusaha smelter juga menginginkan adanya kesetaraan hukum dan perlakuan yang sama kepada pengusaha pertambangan timah.

Penelitian ini merekomendasikan agar pemerintah tetap mempertahankan kebijakan ekspor timah yakni ekspor melalui Bursa Komoditi dan Derivatif Indonesia untuk mencegah ekspor timah ilegal dan meningkatkan daya saing dan nilai tambah produk timah ekspor Indonesia. Selain itu, pemerintah harus lebih pro aktif melakukan diskusi untuk menggali masukan dari para pelaku usaha sehingga dapat menekan perbedaan pendapat antar stakeholder timah.

\section{UCAPAN TERIMA KASIH}

Terima kasih kami sampaikan kepada Kepala Badan Pengkajian dan Pengembangan Kebijakan Perdagangan dan Kepala Pusat Kebijakan Perdagangan Luar Negeri (Puska Daglu), Kementerian Perdagangan yang telah mengizinkan penulis untuk menerbitkan tulisan ini, yang merupakan hasil analisis dari unit Puska Daglu dengan menggunakan DIPA BP2KP tahun 2014.

\section{DAFTAR PUSTAKA}

Anaperta, Y.M. (2012). Optimalisasi Proses Pencucian Kapal Isap Produksi Timah Penganak Dalam Meningkatkan Pencapaian Produksi Di laut Permis. Jurnal Teknologi dan Informasi Pendidikan, Volume 5 Nomor 1 Maret 2012 pp. 122-135. 
Asian Metal. (2014). Tin Price. Diunduh dari http://www.asianmetal.com/TinPrice/ Tin.html Oktober 2014.

BPS. (2014). Statistik Ekspor Impor Indonesia 2014.

Bappebti. (2014). Analisis Harga Timah Januari 2014. Diunduh tanggal 11 November 2014 dari http://www. bappebti.go.id/media/docs/info-komodi ti_2014-02-20_16-09-07_01.10_._ Analisis_Bulanan_Timah-Januari_.pdf.

Baumohl, E., T. Vyrost. (2010). Stock Market Integration: Granger Causality Testing with respect to Nonsynchronous Trading Effects. Finance a úvěr-Czech Journal of Economics and Finance, 60, no. 5 pp. 414-425.

Bisnis com. (2 Mei 2014). Agustus 2013-Maret 2014, Volume Ekspor Timah Tembus 27.809 Ton. Diunduh tanggal 12 Mei 2014 dari http://market. bisnis.com/read/20140502/94/223958/ agustus-2013-maret-2014-volumeekspor-timah-tembus-27.809-ton.

BKDI, (2014). Executive Summary, Agustus 2014 (tidak dipublikasikan).

Bojanic, A.N. (2009). The impact of tin on the economic growth of Bolivia. Coyuntura Económica, Vol. XXXIX, No. 2, pp. 171-183.

Firdaus, M. (2004). Ekonometrika Suatu Pendekatan Aplikatif. Jakarta: Bumi Aksara.

Gatra. (27 Maret 2014). Timah Malaysia dan Thailand van Babel. Diunduh tanggal 23 September 2014 dari http://www. gatra.com/fokus-berita/49793-timahmalaysia-dan-thailand-van-babel.html. Greene, W. H. (2003). Econometric Analysis Fifth Edition. New Jersey: Prentice Hall.
Guo, S., Seth, A. K., Kendrick, K. M., Zhou, C., Feng, J. (2008). Partial Granger causality-Eliminating exogenous inputs and latent variables. Journal of Neuroscience Methods 172 pp. 79-93. Hutton, Laurie. (2014). Tin: how Queensland can help alleviate looming world shortages. Queensland Government Mining Journal, Winter 2014 Vol 111 No. 3 pp. $12-16$.

Infomine. (2014). Tin Price on April 2014. Diunduh 10 April 2014 dari www. infomine.com.

Irawan, R.R., U. Sumarwan., B. Suharjo., S. Djohar. (2014). Model Bisnis Industri Tambang Timah Berkelanjutan (Studi Kasus Bangka Belitung). Jurnal Aplikasi Manajemen Vol. 12 No. 2 pp. 197-207.

Kettle, Peter. (2014). Back from the doldrums? Tin is back on a path to recovery and higher prices may stimulate new project start-ups. Mining Journal 21 Maret 2014 pp. 18 - 21.

Koran Tempo. (6 Mei 2014). Kasus Ekspor Timah Ilegal: Pemerintah Akui Kebobolan.

London Metal Exchange. (2014). Historical Price Data. Diunduh dari www.Ime.com Oktober 2014.

Mareta, Y. (2011). Laporan Umum Magang Tentang Keselamatan dan Kesehatan Kerja di Unit Metalurgi Muntok PT Timah (Persero) Tbk Bangka Belitung. Fakultas Kedokteran Universitas Sebelas Maret. Surakarta.

Ray, S. (2012). Globalization and Economic Growth in India: A Granger Causality Approach. Journal of Law, Policy and Globalization Vol 2, 2012 pp. 18-30. 
Seth, A. K., A. B. Barrett., L. Barnett. (2015). Granger Causality Analysis in Neuroscience and Neuroimaging. The Journal of Neuroscience, Vol. 35 (8) February 25, 2015 pp. 3293-3297.

Steenkamp, J.D., J. Basson. (2013). The Manganese Ferroalloys Industry in Southern Africa. The Journal of The Southern African Institute of Mining and Metallurgy Vol. 113 Agustus 2013 pp. 667-676.
Sutrisno. (2013). Kajian Tinning (Sn Plating) Dalam Dunia Industri. Jurnal Foundry Vol. 3 No. 1 April 2013 pp. 19-24.

Think energy. (2014). Major Tin Producing Countries. Diunduh tanggal 31 Oktober 2014 dari http://www.think-energy.org/ index.php/infographics/401-major-tinproducing-countries. 